\title{
Preliminary PM2.5 and PMIO fractions source apportionment complemented by statistical accuracy determination
}

Lucyna Samek, Zdzislaw Stegowski, Leszek Furman

\begin{abstract}
Samples of PM10 and PM2.5 fractions were collected between the years 2010 and 2013 at the urban area of Krakow, Poland. Numerous types of air pollution sources are present at the site; these include steel and cement industries, traffic, municipal emission sources and biomass burning. Energy dispersive X-ray fluorescence was used to determine the concentrations of the following elements: $\mathrm{Cl}, \mathrm{K}, \mathrm{Ca}, \mathrm{Ti}, \mathrm{Mn}, \mathrm{Fe}, \mathrm{Ni}, \mathrm{Cu}, \mathrm{Zn}, \mathrm{Br}, \mathrm{Rb}$, $\mathrm{Sr}$, As and $\mathrm{Pb}$ within the collected samples. Defining the elements as indicators, airborne particulate matter (APM) source profiles were prepared by applying principal component analysis (PCA), factor analysis (FA) and multiple linear regression (MLR). Four different factors identifying possible air pollution sources for both PM10 and PM2.5 fractions were attributed to municipal emissions, biomass burning, steel industry, traffic, cement and metal industry, $\mathrm{Zn}$ and $\mathrm{Pb}$ industry and secondary aerosols. The uncertainty associated with each loading was determined by a statistical simulation method that took into account the individual elemental concentrations and their corresponding uncertainties. It will be possible to identify two or more sources of air particulate matter pollution for a single factor in case it is extremely difficult to separate the sources.
\end{abstract}

Key words: chemical analysis $\bullet$ particulate matter $\bullet$ source identification

L. Samek ${ }^{凶}$, Z. Stegowski, L. Furman

Faculty of Physics and Applied Computer Science,

AGH University of Science and Technology,

30 Mickiewicza Ave., 30-059 Krakow, Poland,

Tel.: +48 12617 2975, Fax: +48 12617 3400,

E-mail: Lucyna.Samek@fis.agh.edu.pl

Received: 12 August 2015

Accepted: 26 January 2016

\section{Introduction}

Source identification and apportionment of air pollution can be efficiently performed with the use of a variety of statistical methods. Chemical species found in particulate matter can be labelled as source tags. Principal component analysis (PCA) was first applied by Thurston and Spengler to determine the source of particulate matter pollution in Boston [1, 2]. Some interesting examples of the use of PCA in the field of environmental science can be found in literature [3-6]. These analyses include the application of the factor analysis (FA) technique, which is used to study correlations between the measured elemental concentrations at the receptor $[7,8]$. In this method, the components explaining the variance of the elements are extracted and subsequently identified as possible sources. A major disadvantage of PCA is the fact that it does not provide a unique solution because of its simplified approach to factor analysis. However, PCA remains to be widely used for source apportionment [9-11]. Another receptor technique, positive matrix factorisation (PMF), is also commonly applied for source identification [12, 13]. The PMF method was developed by Paatero and Tapper [14] and further modified by Paatero and Hopke [15]. The results of PMF may vary depending on different uncertainty structures [16]. Chemical mass balance (CMB) is also an example of a recep- 
tor model [17]. These methods differ primarily in the extent of knowledge of pollution sources that is required in order to successfully apply the model. The CMB method involves the highest degree of information before its employment. The importance of statistical methods in studies concerning source identification and apportionment is even more pronounced when highly polluted regions are under investigation. The chemical content of airborne particulate matter (APM) is required for such analyses, given that chemical species are the source indicators. Owing to the fact that Krakow is one of the most polluted cities in Poland, it is beneficial to apply statistical analysis to the available air pollution data. The results of such an analysis are expected to lead to decreasing the level of APM in Krakow.

In this work, PCA, FA and multiple linear regression (MLR) were used for the purposes of source identification and apportionment of PM10 and PM2.5 fractions. The main objective of this work was to determine relevant factors and their corresponding uncertainties with the use of both PCA and MLR analysis. The initial air pollution data included results of chemical analysis of samples collected in Krakow, performed by energy dispersive $\mathrm{X}$-ray fluorescence (EDXRF) analysis. Ordinary calculations and statistical analysis were completed using MATLAB; in particular, relevant algorithms from the statistical toolbox were applied.

\section{Methods}

\section{Sampling}

The sampling site was the urban area of Krakow. It was located in the Krowodrza district in the western part of the city (Krakow; 5004'01"N; $19^{\circ} 544^{\prime} 47^{\prime \prime} \mathrm{E}$ in the vicinity of a park. Particulate matter (PM) concentrations at this site are considered as representative of those in the residential areas of the city. The main local sources of pollution at the site are municipal emissions, steel, cement and metal industries and traffic. Traffic density in the city is very high including frequent traffic jams. Factories are located at a distance of approximately $10 \mathrm{~km}$ from the sampling site. Additionally, there are power plants in the southern area of the city. The Upper Silesian industry area is located approximately $80 \mathrm{~km}$ to the west of Krakow. Moreover, the zinc industry is situated approximately $50 \mathrm{~km}$ to the north of the city.

Twenty-four-hour PM10 fraction samples were collected from July 14th to July 22nd 2010, February 22nd to March 3rd 2011 and January 9th to 27th 2012 using a low-volume LVS-3 Sampler with a flow rate of $2.3 \mathrm{~m}^{3} / \mathrm{h}$. Similarly, 24-hour PM2.5 fraction samples were collected from July 15 th to August 6th 2012, January 14th to January 25th 2013 and June 12 th to July 4th 2013 . Teflon PTFE (46.2 mm, $2 \mu \mathrm{m}$ for PM2.5) filters were used as a support. A total of 28 PM10 samples and 47 PM2.5 samples were collected during the following seasons: winter 2011, 2012 and 2013 and summer 2010, 2012 and 2013.

\section{Chemical analysis}

Filters were weighed on a micro-balance (A and D INSTRUMENTS HM-202-EC, accuracy is $0.01 \mathrm{mg}$ ) in an air-conditioned weighing room (temperature: $\left.20 \pm 1^{\circ} \mathrm{C}, \mathrm{RH}: 50 \pm 5 \%\right)$ to evaluate the mass of the PM2.5 fraction, following the procedures outlined in literature $[18,19]$. The weight of the filter was recorded before and after sampling and the average of three separate weightings was reported. The mass of collected dust and volumes of air passing through the sampler were accounted for, when calculating the PM2.5 and PM10 concentrations. The substrates were conditioned for 48 hours in a weighing room before and after sampling. Concentrations of the following elements were determined: $\mathrm{Cl}, \mathrm{K}$, $\mathrm{Ca}, \mathrm{Cr}, \mathrm{Mn}, \mathrm{Fe}, \mathrm{Cu}, \mathrm{Zn}, \mathrm{Br}, \mathrm{Sr}$ and $\mathrm{Pb}$. PM10 and PM2.5 specimens were analysed as thin samples by applying a multifunctional EDXRF spectrometer. The instrument is a micro-beam X-ray fluorescence spectrometer with capillary X-ray optics, a broad X-ray beam from an Mo secondary target, dedicated for X-ray fluorescence (XRF) analysis of bulk samples and a total reflection X-ray technique. The excited X-rays were detected by an $\mathrm{Si}(\mathrm{Li})$ detector with $170 \mathrm{eV}$ resolution at $5.9 \mathrm{keV}$. Data collection was completed using the Canberra system [20]. The measurements were carried out under the following conditions: Mo tube voltage of $55 \mathrm{kV}$, current of $30 \mathrm{~mA}$ and measuring time of $10000 \mathrm{~s}$, in atmospheric air. In order to calculate the concentrations of different elements in the filters, the spectrometer was calibrated using thin-film standards (Micromatter, USA). The XRF spectra were quantitatively analysed using the QXAS package [21]. Table 1 shows the detection limits for the analysed elements.

\section{Statistical analysis}

Possible sources of air pollution in proximity of the sampling site can be qualitatively identified from a correlation matrix. In order to determine the PM10 and PM2.5 emission sources contributing to specific

Table 1. Detection limits $\left[\mathrm{ng} / \mathrm{m}^{3}\right]$. LLD - low limit of detection

\begin{tabular}{lcc}
\hline \multicolumn{1}{c}{ Element } & LLD in PM10 & LLD in PM2.5 \\
\hline $\mathrm{Cl}$ & 64 & - \\
$\mathrm{K}$ & 23 & 15 \\
$\mathrm{Ca}$ & 18 & 7.2 \\
$\mathrm{Ti}$ & 22 & 5.7 \\
$\mathrm{Cr}$ & 13 & 3.0 \\
$\mathrm{Mn}$ & 11 & 2.5 \\
$\mathrm{Fe}$ & 5 & 1.0 \\
$\mathrm{Ni}$ & 5.1 & 1.1 \\
$\mathrm{Cu}$ & 5 & 0.8 \\
$\mathrm{Zn}$ & 4 & 0.6 \\
$\mathrm{Br}$ & 2 & 1.0 \\
$\mathrm{Rb}$ & 3 & 1.0 \\
$\mathrm{Sr}$ & 3 & 1.0 \\
$\mathrm{~Pb}$ & 2 & 1.2 \\
$\mathrm{As}$ & 3 & 1.0 \\
\hline
\end{tabular}


elements, PCA and FA were used. The factor loadings were obtained as a result of the PCA analysis for the PM10 and PM2.5 particles. Additionally, the percentage of variance of each factor was calculated.

Subsequently, MLR was performed to evaluate the contribution of each source group to the PM10 and PM2.5 concentrations. Statistical analysis of the data was completed using MATLAB - the following statistical built-in functions were applied: PRINCOMP, FACTORAN and REGRESS.

In order to improve the significance of the obtained results and allow for their proper interpretation, an additional statistical method was applied to account for uncertainties relevant to the determined factors. Five hundred artificial sets of data were simulated by taking into account the uncertainties (statistical fluctuations) of the elemental concentrations. Supplemental commands were included in the MATLAB code to expand the PCA and MLR calculations. Finally, regular statistical analysis of the results allowed determination of uncertainties for factor loadings.

\section{Results and discussion}

Values of mean PM10, PM2.5 concentrations and elemental concentrations are shown in Table 2. The mean PM10 mass concentration value for the year 2011 exceeded the daily limit value of $50 \mu \mathrm{g} / \mathrm{m}^{3}$ specified by the European Union (EU) Directive [22]. Summer 2010 and winter 2012 values were lower than this limit value. PM2.5 in summer 2012 and 2013 did not exceed target value $25 \mu \mathrm{g} / \mathrm{m}^{3}$ given by the EU Directive [22]. The value for winter 2013 was equal to $74 \mu \mathrm{g} / \mathrm{m}^{3}$ and consequently exceeded the target EU value. The winter-to-summer ratio for the PM10 fraction varied between 1.33 and 3.1. For PM2.5, the winter-to-summer ratio was in the range 4.1-4.6. Significantly higher winter-to-summer ratios were observed for the fine fraction.

Chlorine was observed during winter time for both fractions with the exception of winter 2011, during which the concentration of $\mathrm{Cl}$ was below the detection limit. During summer time, chlorine was not detected in either one of the analysed fractions. The source of chlorine may be municipal emissions or it can be introduced to air whilst deicing pavements and streets during winter.

Concentrations of potassium were higher during winter time for the PM10 fraction with the exception of winter 2012, during which a low concentration of potassium was observed. The winter-to-summer ratio was in the range of $0.76-1.5$. A significant difference between winter and summer concentrations was observed for the PM2.5 fraction. The winter-to-summer ratio varied from 9.2 to 13.5 . In winter time, elevated concentrations of potassium were detected. This increase was very pronounced in the PM2.5 fraction. The potential sources of potassium are municipal emissions, combustion and biomass burning.

Concentrations of calcium in the PM10 fraction were comparable during winter and summer. An exception was observed during winter 2012, during which the mean concentration of calcium was two times higher than that for summer 2010 and winter 2011. Similar concentrations of calcium were observed in the PM2.5 fraction with the exception of summer 2013. The winter-to-summer ratio was 3.0.

Titanium was detected in the PM10 fraction only. Concentrations of manganese were higher in the PM10 than in the PM2.5 fraction. Concentrations of iron in PM10 in summer 2010 were similar to that in winter 2011. In contrast, in winter 2012, the amount of iron was two times lower than in the previous years. The PM2.5 fraction concentrations of iron were two times higher in summer than in winter. Copper had similar concentrations in PM10 fraction for winter and summer with the exception of winter 2012, during which a low concentration of copper was determined. The PM2.5 fraction concentration of copper was five times lower in winter than in summer. It can be also seen that concentrations of copper were higher in PM10 in comparison to PM2.5. Concentrations of

Table 2. Mean PM10 and PM2.5 concentrations $\left[\mu \mathrm{g} / \mathrm{m}^{3}\right]$ and mean elemental concentrations in PM10 and PM2.5 $\left[\mathrm{ng} / \mathrm{m}^{3}\right]$. St. dev. - variability of results in measuring period; <LLD - values below detection limit

\begin{tabular}{lcccccc}
\hline & \multicolumn{5}{c}{ Mean \pm St. dev. } \\
\cline { 2 - 7 } & PM10 & PM10 & PM10 & PM2.5 & PM2.5 & PM2.5 \\
& Summer 2010 & Winter 2011 & Winter 2012 & Summer 2012 & Winter 2013 & Summer 2013 \\
\hline $\mathrm{PM}$ & $30 \pm 7$ & $93 \pm 25$ & $40 \pm 21$ & $18 \pm 6$ & $74 \pm 38$ & $16 \pm 4$ \\
$\mathrm{Cl}$ & $<\mathrm{LLD}$ & $<\mathrm{LLD}$ & $1040 \pm 376$ & $<\mathrm{LLD}$ & $2116 \pm 2400$ & $<$ LLD \\
$\mathrm{K}$ & $254 \pm 84$ & $386 \pm 102$ & $193 \pm 168$ & $180 \pm 78$ & $1666 \pm 897$ & $123 \pm 68$ \\
$\mathrm{Ca}$ & $488 \pm 476$ & $452 \pm 480$ & $918 \pm 555$ & $353 \pm 410$ & $440 \pm 326$ & $146 \pm 73$ \\
$\mathrm{Ti}$ & $37 \pm 18$ & $66 \pm 13$ & $17 \pm 20$ & $<$ LLD & $<$ LLD & $<$ LLD \\
$\mathrm{Mn}$ & $26 \pm 11$ & $52 \pm 28$ & $16 \pm 10$ & $4.5 \pm 2.9$ & $7.5 \pm 14$ & $8.4 \pm 5.1$ \\
$\mathrm{Fe}$ & $1088 \pm 615$ & $1300 \pm 645$ & $507 \pm 470$ & $208 \pm 112$ & $130 \pm 101$ & $234 \pm 133$ \\
$\mathrm{Ni}$ & $<\mathrm{LLD}$ & $<\mathrm{LLD}$ & $<$ LLD & $0.6 \pm 0.2$ & $<$ LLD & $<$ LLD \\
$\mathrm{Cu}$ & $22.5 \pm 7.3$ & $23 \pm 13$ & $8.7 \pm 4.0$ & $8.9 \pm 6.5$ & $1.8 \pm 7.8$ & $5.5 \pm 3.5$ \\
$\mathrm{Zn}$ & $76 \pm 34$ & $176 \pm 50$ & $141 \pm 62$ & $47 \pm 18$ & $151 \pm 77$ & $67 \pm 35$ \\
$\mathrm{Br}$ & $6.3 \pm 2.1$ & $33 \pm 10$ & $49 \pm 27$ & $8.6 \pm 2.5$ & $8 \pm 11$ & $4.7 \pm 1.2$ \\
$\mathrm{Rb}$ & $<\mathrm{LLD}$ & $<\mathrm{LLD}$ & $<$ LLD & $<$ LLD & $20 \pm 9$ & $1.0 \pm 0.4$ \\
$\mathrm{Sr}$ & $8.5 \pm 1.0$ & $4.5 \pm 3.0$ & $43.3 \pm 8.1$ & $6 \pm 5$ & $<$ LLD & $<$ LLD \\
$\mathrm{Pb}$ & $26 \pm 6$ & $52 \pm 17$ & $41 \pm 19$ & $14.7 \pm 4.9$ & $30 \pm 31$ & $13 \pm 5$ \\
$\mathrm{As}$ & $<$ LLD & $8 \pm 6$ & $<$ LLD & $0.9 \pm 0.3$ & $<$ LLD & $<$ LLD \\
\hline
\end{tabular}


Table 3. The factor loadings and uncertainties obtained as a result of the PCA for the PM10 fraction

\begin{tabular}{|c|c|c|c|}
\hline Element & $\begin{array}{l}\text { Factor } 1 \\
\text { Municipal emission, biomass } \\
\text { burning/steel industry/traffic }\end{array}$ & $\begin{array}{c}\text { Factor } 2 \\
\text { Cement industry/ } \\
\text { metallurgical industry }\end{array}$ & $\begin{array}{c}\text { Factor } 3 \\
\mathrm{Zn} \text { and } \mathrm{Pb} \text { industries }\end{array}$ \\
\hline$\overline{\mathrm{K}}$ & $0.752 \pm 0.092$ & $0.123 \pm 0.101$ & $0.218 \pm 0.200$ \\
\hline $\mathrm{Ca}$ & $0.400 \pm 0.070$ & $0.684 \pm 0.079$ & $0.107 \pm 0.188$ \\
\hline $\mathrm{Cr}$ & $-0.174 \pm 0.142$ & $0.827 \pm 0.093$ & $0.165 \pm 0.404$ \\
\hline $\mathrm{Mn}$ & $0.841 \pm 0.037$ & $-0.130 \pm 0.058$ & $0.294 \pm 0.145$ \\
\hline $\mathrm{Fe}$ & $0.980 \pm 0.052$ & $0.003 \pm 0.052$ & $0.113 \pm 0.208$ \\
\hline $\mathrm{Cu}$ & $0.682 \pm 0.043$ & $-0.251 \pm 0.061$ & $0.251 \pm 0.126$ \\
\hline $\mathrm{Zn}$ & $0.406 \pm 0.116$ & $0.253 \pm 0.142$ & $0.770 \pm 0.419$ \\
\hline $\mathrm{Br}$ & $0.002 \pm 0.039$ & $0.381 \pm 0.055$ & $0.243 \pm 0.148$ \\
\hline $\mathrm{Sr}$ & $-0.195 \pm 0.057$ & $0.978 \pm 0.070$ & $0.032 \pm 0.178$ \\
\hline $\mathrm{Pb}$ & $0.524 \pm 0.113$ & $0.290 \pm 0.142$ & $0.798 \pm 0.413$ \\
\hline$\%$ Variance & 68.600 & 29.692 & 1.209 \\
\hline
\end{tabular}

zinc were higher in winter than in summer in both the fractions. However, values of zinc concentrations in PM10 were comparable to that in PM2.5 during equivalent seasons. For bromine, the winter-to-summer ratios for the PM10 fraction were as follows: 5.2 (winter 2011) and 7.8 (winter 2012). No difference between summer and winter was observed for bromine in the PM2.5 fraction. A similar trend was observed for lead. Nickel was observed in PM2.5 fraction only in summer 2012.

Factor loadings of element data are shown in Tables 3 and 4, for both PM10 and PM2.5 fractions. Three factors were obtained for the PM10 fraction from PCA and FA methods. The variance of the first factor was $68.6 \%$, that of the second was $29.7 \%$ and the third had a variance of $1.2 \%$. The trace elements corresponding to the first factor were as follows: $\mathrm{K}, \mathrm{Mn}, \mathrm{Fe}, \mathrm{Cu}$ and $\mathrm{Pb}$. These were the ones with high correlation coefficients. Three sources were identified on the basis of the presence of these elements. They were combustion (municipal emission, biomass burning, K, Fe) [23], steel industry (Nowa Huta steel mill, Fe, Mn) [24] and traffic $(\mathrm{Cu}, \mathrm{Pb})$ [25, 26], (Factor 1, Table 3). The presence of $\mathrm{Cu}$ in PM can be attributed to the wearing of brake pads [13]. Potassium can be attributed to municipal emissions and biomass burning. The mean contribution value of Factor 1 for summer and winter was equal to $74 \%$. For the second factor, the tracers were $\mathrm{Ca}$, $\mathrm{Cr}$ and $\mathrm{Sr}$. The presence of these elements points to cement and metallurgical processes [24]. It can be also attributed to soil source during summer season. The mean contribution of Factor 2 was $2.8 \%$ in summer and winter 2011 and 8.2\% in winter 2012. The following elements were found in the third factor: $\mathrm{Zn}$ and $\mathrm{Pb}$. This factor can be attributed to the $\mathrm{Zn}$ and $\mathrm{Pb}$ industries (ore mining and processing) located at a distance of approximately $50 \mathrm{~km}$ from Krakow. This factor can also identify the source as traffic. The mean contribution value was $12.4 \%$ for summer and $9 \%$ for winter. The mean contribution of a non-identified source (Factor 0, Fig. 3) was equal to $10.8 \%$ for summer and $9.3 \%$ for winter. Secondary aerosols such as sulphate and nitrate can be related to this source. Samek et al. [24] performed research in the years 2009 and 2010 for PM10 in Krakow and presented source identification and apportionment (PCA, FA and MLR) by using STATISTICA software. Samples were collected at industrial area of the city (Nowa Huta steel mill). In their paper, the following sources were identified in PM10 fraction in winter: combustion $(\mathrm{K}, \mathrm{Zn}$, $\mathrm{Cu}, \mathrm{As})$ with mean contribution $61 \%$; industry $(\mathrm{Ca}$, $\mathrm{Cr}, \mathrm{Mn}, \mathrm{Fe}-$ steel mill) with mean contribution of $29 \%$ and about $10 \%$ of non-identified source (it can be secondary aerosols, sulphate, nitrate). During summer, about $60 \%$ of non-identified source, $23 \%$ of industry (K, Ca, Mn, Fe, Zn) and 15\% of traffic (Br, As) as well as $2 \%$ crustal (Ti, Cr) were detected. In the paper [4], studies were performed in winter

Table 4. The factor loadings and uncertainties obtained as a result of the PCA for the PM2.5 fraction

\begin{tabular}{lccc}
\hline & $\begin{array}{c}\text { Factor } 1 \\
\text { Eteel and cement } \\
\text { industries/traffic }\end{array}$ & $\begin{array}{c}\text { Factor } 2 \\
\text { Combustion }\end{array}$ & $\begin{array}{c}\text { Factor } 3 \\
\text { Road dust }\end{array}$ \\
\hline $\mathrm{K}$ & $0.048 \pm 0.045$ & $\mathbf{0 . 9 8 5} \pm \mathbf{0 . 1 1 0}$ & $0.153 \pm 0.132$ \\
$\mathrm{Ca}$ & $\mathbf{0 . 8 8 7} \pm \mathbf{0 . 0 5 3}$ & $0.385 \pm 0.088$ & $0.134 \pm 0.066$ \\
$\mathrm{Mn}$ & $0.193 \pm 0.065$ & $0.184 \pm 0.088$ & $\mathbf{0 . 5 8 2} \pm \mathbf{0 . 1 5 0}$ \\
$\mathrm{Fe}$ & $\mathbf{0 . 5 7 2} \pm \mathbf{0 . 0 3 6}$ & $-0.080 \pm 0.102$ & $\mathbf{0 . 5 4 9} \pm \mathbf{0 . 1 4 4}$ \\
$\mathrm{Cu}$ & $\mathbf{0 . 9 0 7} \pm \mathbf{0 . 0 6 7}$ & $-0.034 \pm 0.109$ & $0.123 \pm 0.065$ \\
$\mathrm{Zn}$ & $0.051 \pm 0.063$ & $\mathbf{0 . 5 8 8} \pm \mathbf{0 . 0 8 5}$ & $\mathbf{0 . 8 0 4} \pm \mathbf{0 . 1 0 1}$ \\
$\mathrm{Br}$ & $0.024 \pm 0.045$ & $0.176 \pm 0.075$ & $\mathbf{0 . 5 0 6} \pm \mathbf{0 . 0 8 3}$ \\
$\mathrm{Rb}$ & $-0.058 \pm 0.056$ & $\mathbf{0 . 8 7 7} \pm \mathbf{0 . 1 0 6}$ & $0.272 \pm 0.127$ \\
$\mathrm{Sr}$ & $\mathbf{0 . 9 7 7} \pm \mathbf{0 . 0 6 7}$ & $-0.097 \pm 0.085$ & $0.049 \pm 0.043$ \\
$\mathrm{~Pb}$ & $0.089 \pm 0.057$ & $\mathbf{0 . 6 0 9} \pm \mathbf{0 . 0 8 9}$ & $0.430 \pm 0.124$ \\
$\%$ Variance & 79.885 & 17.899 & 2.057 \\
\hline
\end{tabular}




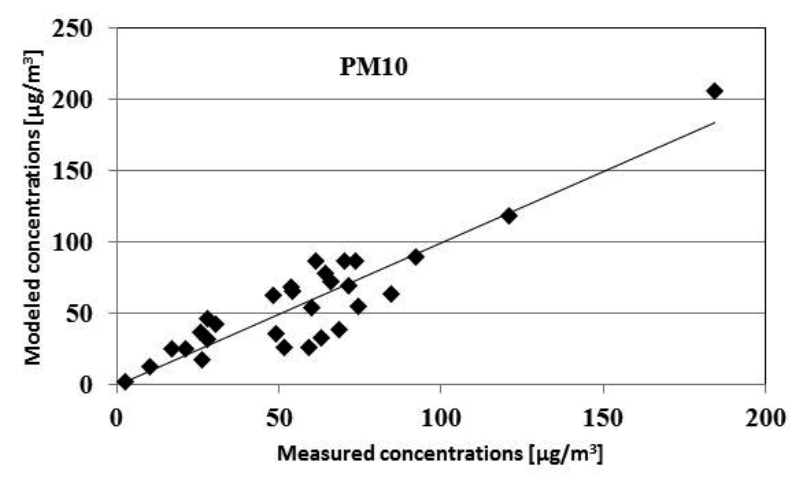

Fig. 1. Modelled (MLR) vs. measured PM10 concentrations.

2010 in two different sites in Krakow (industrial and residential). At both sites, three factors were observed. In Nowa Huta, one factor describing two sources, combustion and traffic $(\mathrm{Cu}, \mathrm{Zn}, \mathrm{Br}, \mathrm{As})$, were determined with the contribution of $53.1 \%$. Second factor describing industry and wood combustion (K, Ca, Mn, Fe) with $28.5 \%$ contribution and the last non-identified source with contribution of $18.3 \%$. In the residential area, combustion and traffic $(\mathrm{Cu}, \mathrm{Zn}, \mathrm{Br}, \mathrm{Pb}, \mathrm{As})$ contributed to $46.5 \%$, industry and wood combustion $(\mathrm{K}, \mathrm{Ca}, \mathrm{Fe})$ contributed to $50.4 \%$ as well as non-identified source contributed to $3.5 \%$. In the current studies, statistical analysis was done using MATLAB. This tool did not lead to good separation of sources. One factor corresponds to three identified sources of pollution. But the advantage is that it is possible to determine the uncertainties of the obtained results. Figure 1 presents results obtained from the MLR analysis. Mass concentrations predicted by the model were compatible with those measured. Figure 2 shows the contribution of each factor to the total PM10 mass. Figures 3-6 show the contribution of each factor to PM10 separately. Additionally, uncertainties for each factor were determined. The factors contributing to PM10 were defined in Table 3. Factor 0 can be attributed to a non-identified source. This source could potentially be secondary aerosols (nitrate and sulphate). Its contribution to PM10 was in the range of $4-18 \%$ during the entire period of measurements. Factor 1, identified as combustion or industry or traffic source, contributed to 60-90\%. It would be beneficial to extend this analysis to allow for the separation of these three sources. Factor 2 (Table 3) identified as cement or metallurgical industry contributed 3\% to PM10 during the first period of study and increased to approximately 15\% during winter 2012. In summer Factor 2 can also be responsible for soil pollution. Factor 3 (Table 3) identified as $\mathrm{Zn}$ and $\mathrm{Pb}$ industries (ore mining and processing) or traffic contributed in the range of 3-20\%. The successful identification of these sources can be confirmed by evaluating backward trajectories obtained for the days of high contribution. The $\mathrm{Zn}$ and $\mathrm{Pb}$ industry is located in the North West direction from Krakow. During the days of high contribution of this factor - 14 July 2010, 19 July 2010 and 12 January 2012 inflow of air mass was directed to Krakow from the North West. (Backward trajectories were not shown in this work).

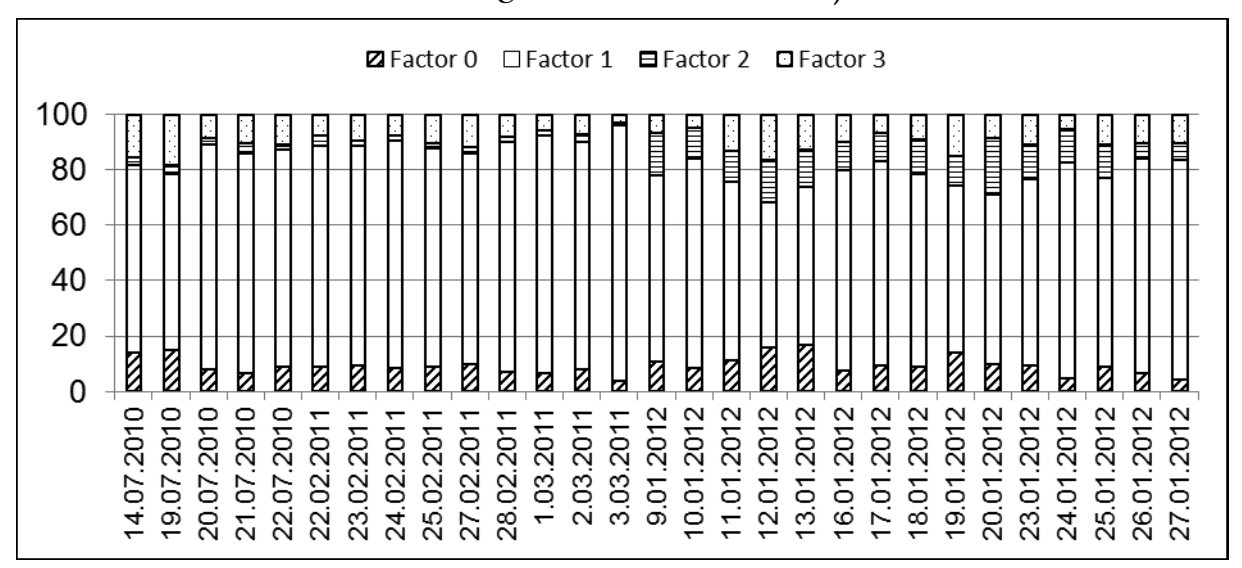

Fig. 2. Contribution of factors to total PM10.

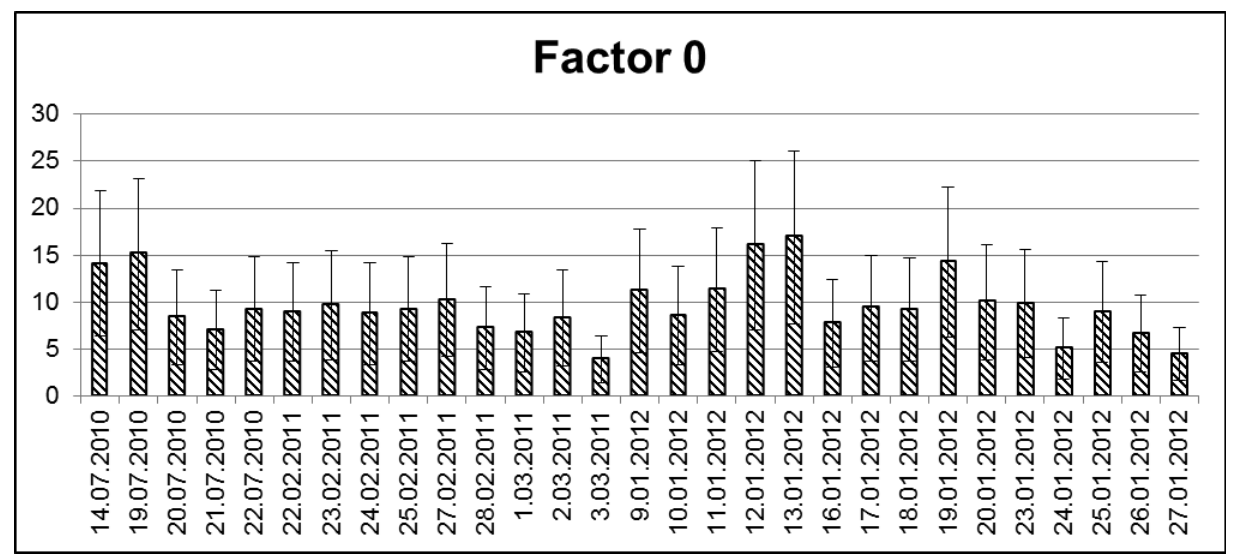

Fig. 3. Contribution of Factor 0 to total PM10 with uncertainties. 


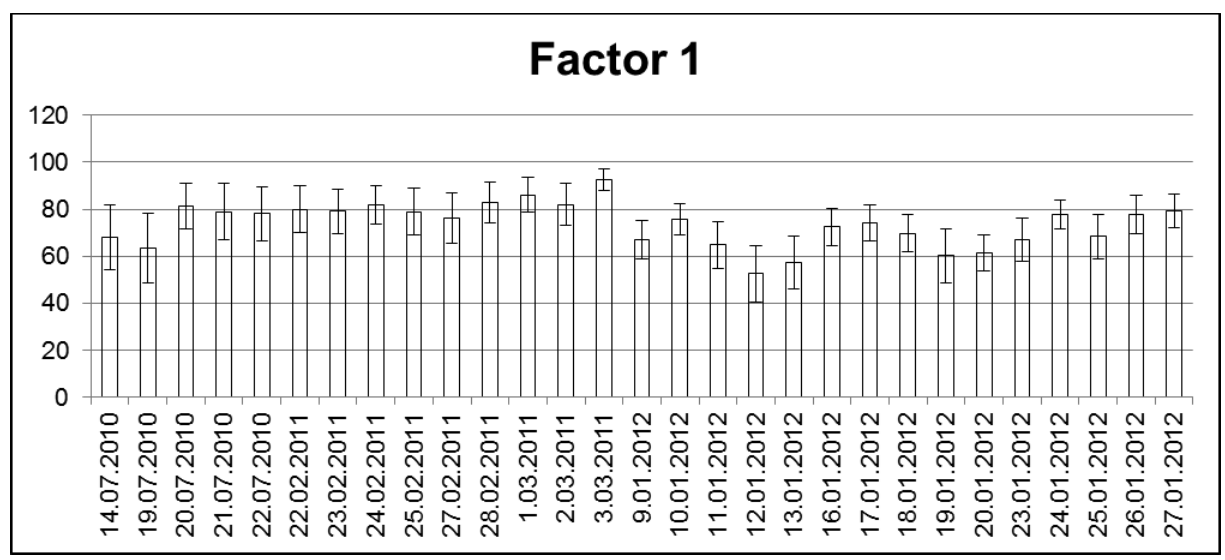

Fig. 4. Contribution of Factor 1 to total PM10 with uncertainties.

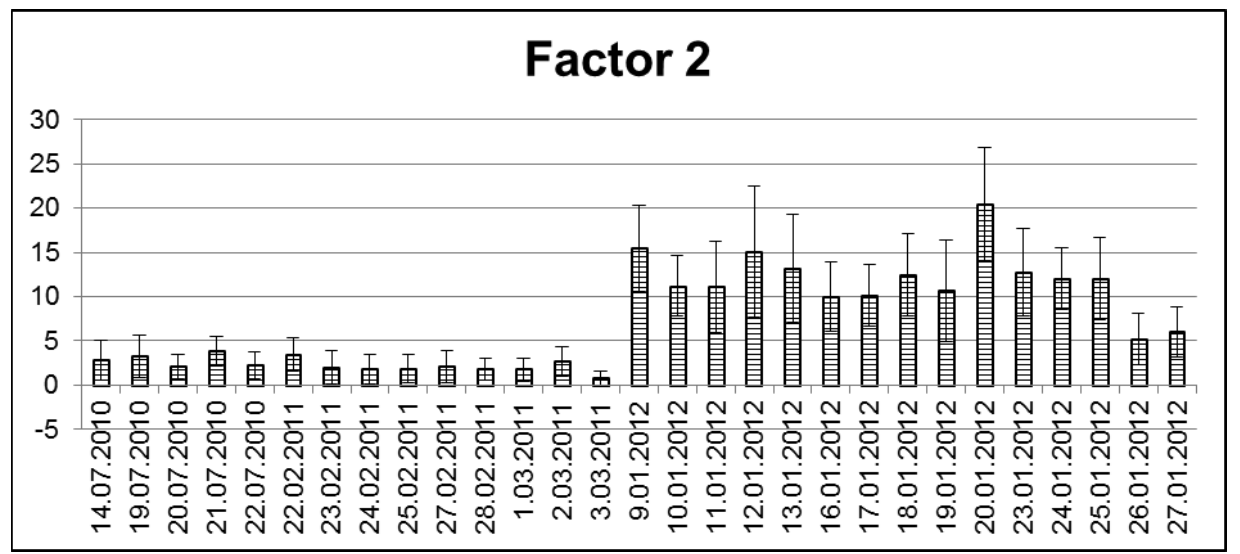

Fig. 5. Contribution of Factor 2 to total PM10 with uncertainties.

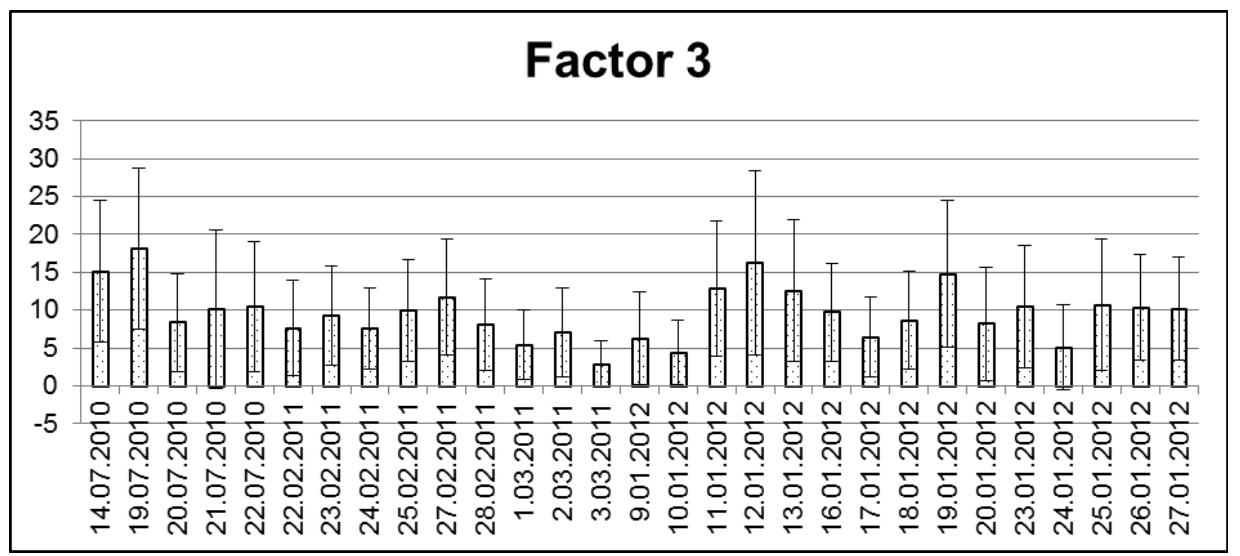

Fig. 6. Contribution of Factor 3 to total PM10 with uncertainties.

PCA and FA factor loadings for PM2.5 are shown in Table 4. The first factor characterized by $\mathrm{Ca}, \mathrm{Fe}$, $\mathrm{Cu}$ and $\mathrm{Sr}$ can be attributed to industry (Nowa Huta steel mill and cement industry) and traffic sources. The second factor was identified by $\mathrm{K}, \mathrm{Rb}, \mathrm{Zn}$ and $\mathrm{Pb}$ and can be associated with combustion (biomass) and traffic. The third factor identified by $\mathrm{Mn}, \mathrm{Fe}, \mathrm{Br}$, $\mathrm{Zn}$ and $\mathrm{Pb}$ can be attributed to road dust. Figure 7 shows the PM2.5 mass concentrations as predicted by the model and resulting from the experiment. Figure 8 shows contributions of different sources to PM2.5 mass, and Figs. 9-12 present contributions to each factor with calculated uncertainties. Factor 0 (Fig. 9) characterised a non-identified source, which could be secondary aerosols. The contribution of this factor to PM2.5 during winter time varied from $1 \%$ to $4 \%$ and during summer $2-8 \%$. The mean value was $1.8 \%$ for winter and $3.9 \%$ for summer. The first factor implied industry and traffic contributed $70-80 \%$ to the total mass. During winter time, the values were slightly lower than those during summer time. Mean value was $75.1 \%$ for winter and $80 \%$ for summer. The second factor described by combustion contributed $10-30 \%$ in winter and $5-20 \%$ in summer. The mean value was $20.5 \%$ for winter and $12.1 \%$ for summer. Contribution of the third source was $2-7 \%$ in summer and $1-5 \%$ in winter. Table 5 presents statistical parameters for MLR for both fractions and all factors. The study by Samek et al. [5] is considering source identification and apportionment of PM2.5 collected 


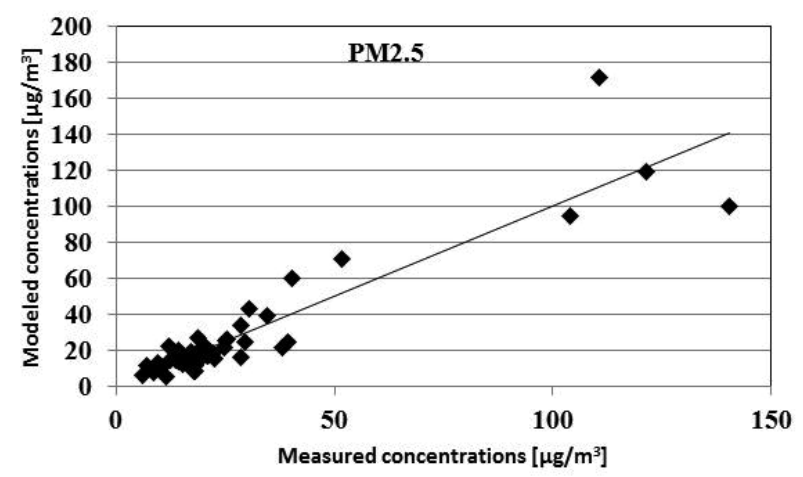

Fig. 7. Modelled (MLR) vs. measured PM2.5 concentrations. in residential area of Krakow. Three factors were presented in winter 2011 and summer 2012. In winter, first factor corresponds to municipal emission and industry (K, $\mathrm{Ca}, \mathrm{Fe}, \mathrm{Zn}, \mathrm{Sr}$ ) with mean contribution of $49.2 \%$, second factor is responsible for traffic $(\mathrm{Br}$, $\mathrm{Pb}$ ) with mean contribution of $37.8 \%$ as well as non-identified source (third factor) with contribution of $13 \%$. During summer, traffic $(\mathrm{Cu}, \mathrm{Br}, \mathrm{Pb})$ reaches the contribution of $53 \%$, industry (Ca, Mn, Fe, Sr) $18 \%$ and non-identified source $29 \%$. Viana et al. [8] wrote paper about source apportionment in Europe (review). They described six main sources of pollution characterised by individual chemical species in different cities in Europe.

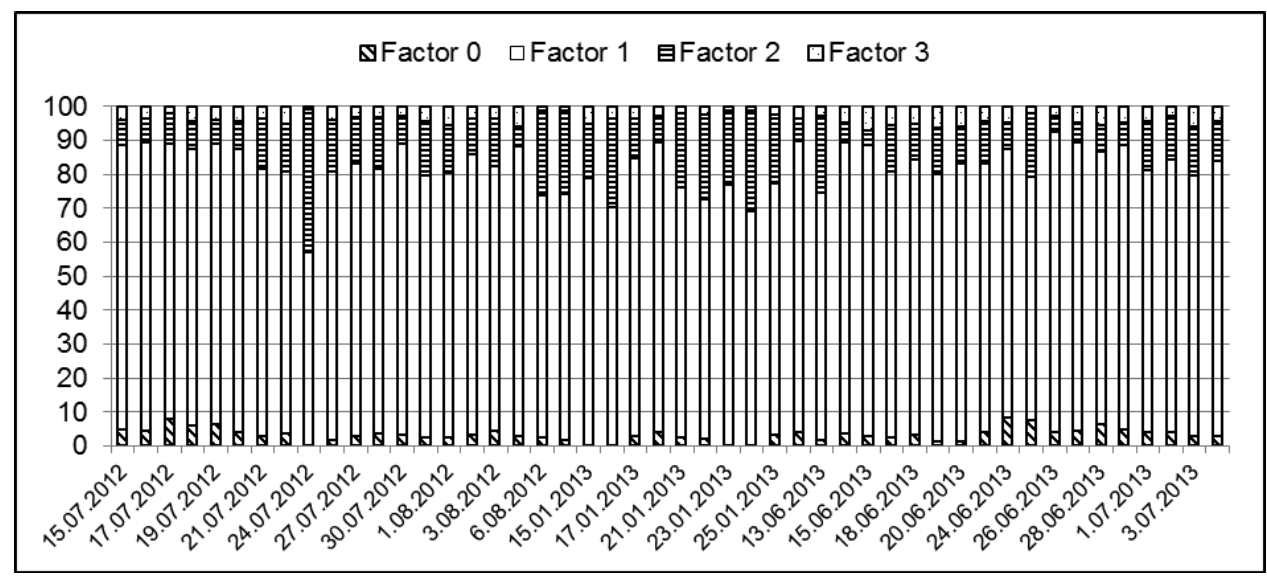

Fig. 8. Contribution of factors to total PM2.5.

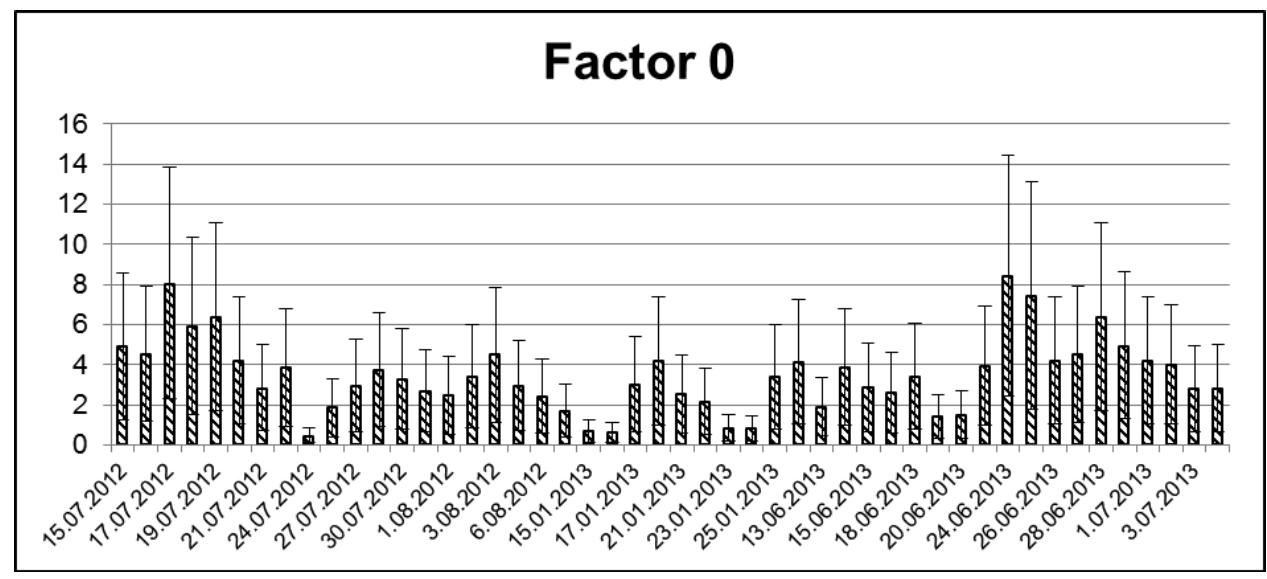

Fig. 9. Contribution of Factor 0 to total PM2.5 with uncertainties.

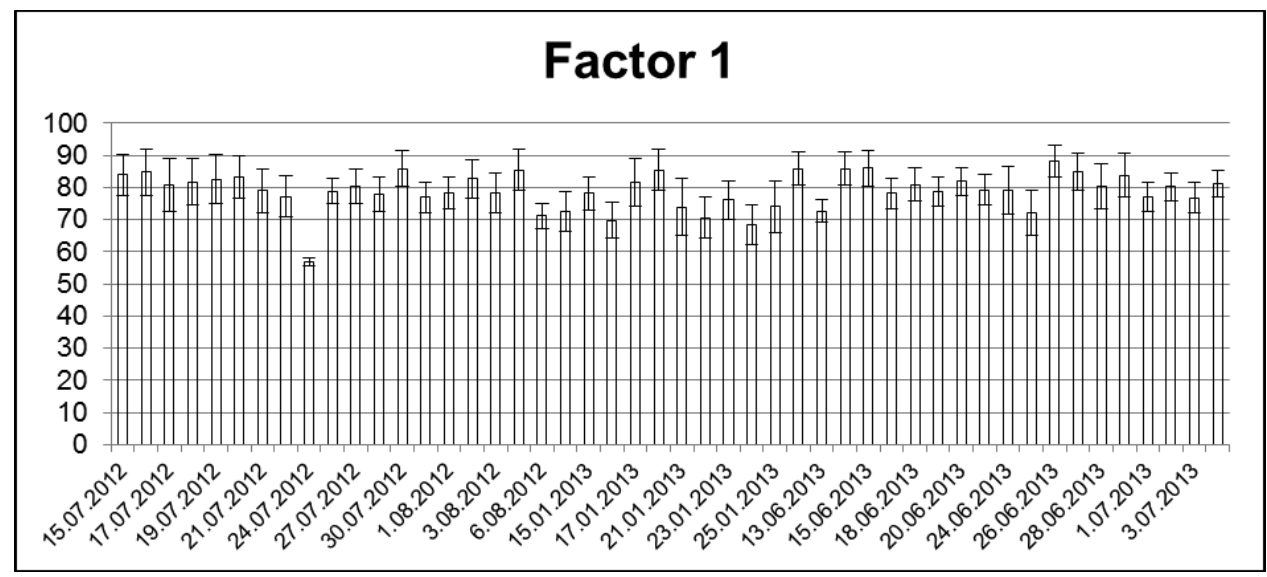

Fig. 10. Contribution of Factor 1 to total PM2.5 with uncertainties. 


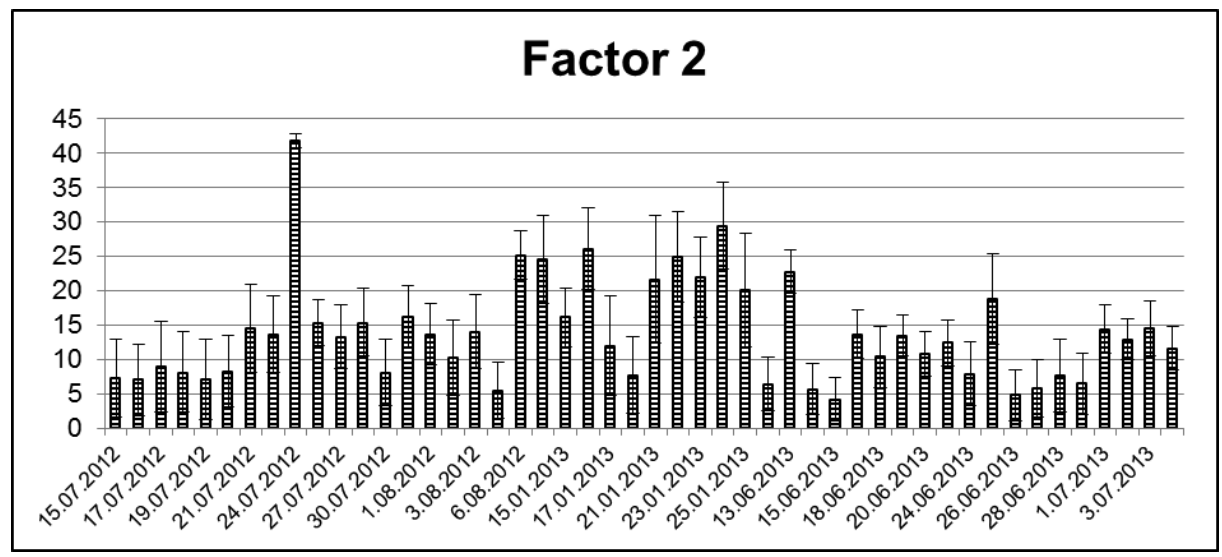

Fig. 11. Contribution of Factor 2 to total PM2.5 with uncertainties.

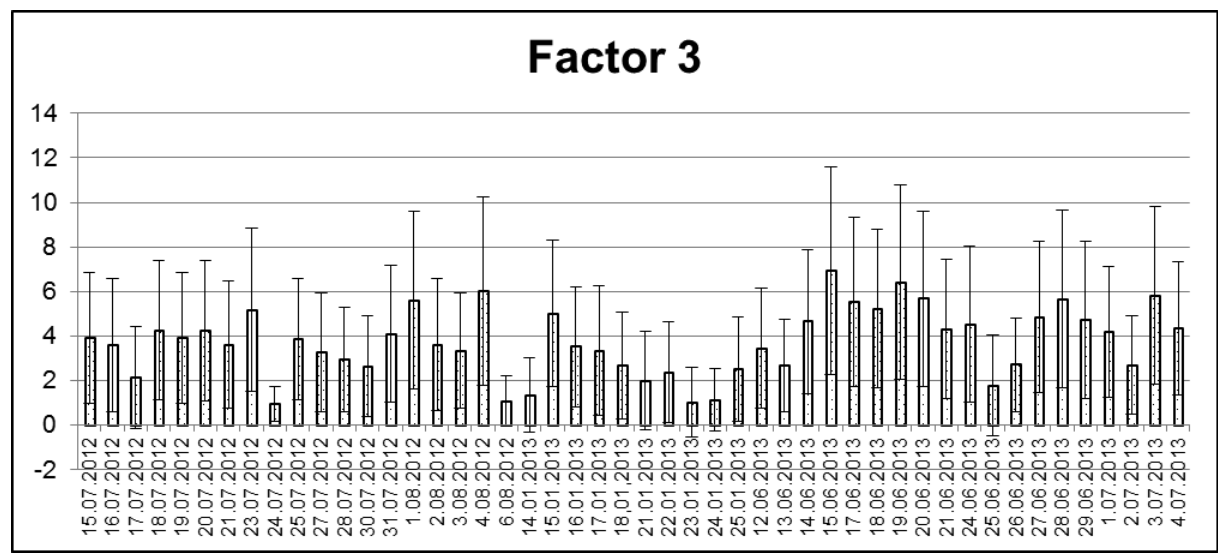

Fig. 12. Contribution of Factor 3 to total PM2.5 with uncertainties.

\section{Conclusions}

High concentrations of both PM10 and PM2.5 fractions were observed during the sampling periods at the site of Krakow, Poland. In particular, they were significantly elevated during winter time. At that time, both the limit value for PM10 and the target value for PM2.5 were exceeded. Trends in the concentrations of $\mathrm{Cl}$ and $\mathrm{K}$ uncovered seasonal variations for both investigated fractions. Not surprisingly, most elements had higher concentrations in winter. However, fine fraction data revealed lower concentration of $\mathrm{Cu}$ during winter. PCA, FA and MLR methods were applied for approximate source identification. For each determined factor loading, the uncertainty was estimated by means of statistical simulation.

Table 5. Coefficients of multilinear regression (MLR) for PM10 and PM2.5 fractions

\begin{tabular}{lc}
\hline \multicolumn{3}{c}{ MLR for PM10 } \\
\hline a0 (F0) & $5.6 \pm 5.3$ \\
a1 (F1) & $16.5 \pm 0.51$ \\
a2 (F2) & $3.8 \pm 1.3$ \\
a3 (F3) & $11.0 \pm 3.7$ \\
\hline \multicolumn{3}{c}{ MLR for PM2.5 } \\
\hline a0 (F0) \\
a1 (F1) & $0.1 \pm 0.8$ \\
a2 (F2) & $11.8 \pm 0.5$ \\
a3 (F3) & $9.6 \pm 0.9$ \\
\hline
\end{tabular}

In several cases, it was impossible to distinguish sources of APM pollution in Krakow. For this reason, there exists a need to include more chemical species to enhance the meaningfulness of the data interpretation.

Acknowledgments. The International Atomic Energy Agency, project no. RER/1/008, together with the Polish Ministry of Science and Higher Education and its grants for scientific research partially financed this work. The authors gratefully acknowledge the NOAA Air Resources Laboratory (ARL) for the provision of the HYSPLIT transport and dispersion model and READY website (http://www.ready.noaa.gov) used in this publication.

\section{References}

1. Thurston, G. D., \& Spengler, J. D. (1985). A quantitative assessment of source contributions to inhalable particulate matter pollution in Metropolitan Boston. Atmos. Environ., 19, 9-25.

2. Thurston, G. D., \& Spengler, J. D. (1985). A multivariate assessment of meteorological influences on inhalable particle source impacts. J. Clim. Appl. Meteorol., 24, 1245-1256.

3. Song, Y., Xie, S., Zhang, Y., Zeng, L., Salmon, L. G. \& Zheng, M. (2006). Source apportionment of PM2.5 in Beijing using Principal Component Analysis/ Absolute Principal Component scores and UNMIX. 
Sci. Total Environ., 372, 278-286. DOI: 10.1016/j. scitotenv.2006.08.041.

4. Samek, L. (2012). Source apportionment of PM10 fraction of particulate matter collected in Krakow, Poland. Nukleonika, 57(4), 601-606.

5. Samek, L., Gdowik, A., Ogarek, J., \& Furman, L. (2016). Elemental composition and rough source apportionment of fine particulate matter in Krakow, Poland. Environ. Prot. Eng. (in press).

6. Almeida, S. M., Pio, C. A., Freitas, M. C., Reis, M. A., \& Trancoso, M. A. (2006). Approaching PM2.5 and PM2.5-10 source apportionment by mass balance analysis, principal component analysis and particle size distribution. Sci. Total Environ., 368, 663-674. DOI: 10.1016/j.scitotenv.2006.03.031.

7. Pandolfi, M., Viana, M., Minguillon, M. C., Querol, X., Alastuey, A., Amato, F., Celades, I., Escrig, A., \& Monfort, E. (2008). Receptor models application to multi-year ambient PM10 measurements in an industrialized ceramic area: Comparison of source apportionment results. Atmos. Environ., 42, 9007-9017. DOI: 10.1016/j.atmosenv.2008.09.029.

8. Viana, M., Kuhlbusch, T. A. J., Querol, X., Alastuey, A., Harrison, R. M., Hopke, P. K., Winiwarter, W., Vallius, M., Szidat, S., Prevot, A. S. H., Hueglin, C., Bloemen, H., Wahlin, P., Vecchi, R., Miranda, A. I., Kasper-Giebl, A., Maenhaut, W., \& Hitzenberger, R. (2008). Source apportionment of particulate matter in Europe: A review of methods and results. Aerosol Sci., 39, 827-849. DOI: 10.1016/j.jaerosci.2008.05.007.

9. Almeida, M., Pio, C. A., Freitas, M. C., Reis, M. A., \& Trancoso, M. A. (2005). Source apportionment of fine and coarse particulate matter in sub-urban area at Western European Coast. Atmos. Environ., 39, 3127-3138. DOI: 10.1016/j.atmosenv.2005.01.048.

10. Almeida, S. M., Reis, M. A., Freitas, M. C., \& Pio, C. A. (2007). Quality assurance in elemental analysis of airborne particles. Nucl. Instrum. Methods Phys. Res. Sect. B-Beam Interact. Mater. Atoms, 207, 434-446. DOI: $10.1016 /$ so168-583x(03)01119-4.

11. Vallius, M., Janssen, N. A. H., Heinrich, J., Hoek, G., Ruuskanen, J., Cyrys, J., Van Grieken, R., de Hartog, J. J., Kreyling, W. G., \& Pekkanen, J. (2005). Sources and elemental composition of ambient PM2.5 in three European cities. Sci. Total Environ., 337, 147-162. DOI: 10.1016/j.scitotenv.2004.06.018.

12. Hasheminassab, S., Daher, N., Ostro, B. D., \& Siontas, C. (2014). Long term source apportionment of ambient fine particulate matter (PM2.5) in the Los Angeles basin: A focus on emissions reduction from vehicular sources. Environ. Pollut., 193, 54-64. DOI: 10.1016/j.envpol.2014.06.012.

13. Callen, M. S., Iturmendi, A., \& Lopez, J. M. (2014). Source apportionment of atmospheric PM2.5 bound polycyclic aromatic hydrocarbons by a PMF receptor model. Assessment of potential risk for human health Environ. Pollut., 195, 167-177. DOI: 10.1016/j. envpol.2014.08.025.

14. Paatero, P., \& Tapper, U. (1994). Positive matrix factorization: non negative factor model with optimal utilization of error estimates of data values. Environmetrics, 5, 111-126. DOI: 10.1002/env3170050203.

15. Paatero, P., \& Hopke, P. K. (2003). Discarding or downweighting high noise variables in factor analytic models. Anal. Chim. Acta, 490, 277-289. DOI: 10.1016/S0003-2670(02)01643-4.

16. Kim, E., Hopke, P. K., \& Qin, Y. (2005). Estimation of organic carbon blank values and error structures of the speciation trends network data for source apportionment. J. Air Waste Manag. Assoc., 55, 1190-1199.

17. Hopke, P. K., Ito, K., Mar, T., Christensen, W. F., Eatough, D. J., Henry, R. C., Kim, E., Laden, F., Lall, R., Larson, T. V., Liu, H., Neas, L., Pinto, J., Stölzel, M., Suh, H., Paatero, P., \& Thurston, G. D. (2006). PM source apportionment and health effects: Intercomparison of source apportionment results. J. Expo. Sci. Environ. Epidemiol., 16, 275-286. DOI: 10.1038/ si.jea. 7500458.

18. PN-EN 12341. (2006). Air quality-determination of the PM10 fraction of suspended particulate matter reference method and field test procedure to demonstrate reference equivalence of measurement methods.

19. PN-EN 14907. (2006). Ambient air quality-standard gravimetric measurement method for the determination of the PM2.5 mass fraction of suspended particular matter.

20. http://www.canberra.com (accessed 12 August 2015).

21. Vekemans, B., Janssens, K., Vincze, L., Adams, F., \& Van Espin, P. (1994). Analysis of X-ray spectra by iterative least squares (AXIL): new developments. $X$-Ray Spectrom., 23, 278-285.

22. Directive 2008/50/EC of the European Parliament and of the Council of 21 May 2008.

23. Begun, B. A., Hopke, P. K., \& Zhao, W. (2005). Source identification of fine particles in Washington, DC, by expanded factor analysis modelling. Environ. Sci. Technol., 39, 1129-1137. DOI: 10.1021/es049804v.

24. Samek, L., Zwozdziak, A., \& Sowka, I. (2013). Chemical characterization and source identification of particulate matter PM10 in a rural and urban site in Poland. EPE, 39, 91-103. DOI: 10.5277/epe130408.

25. Lammel, G., Rohrl, A., \& Schreiber, H. (2002). Atmospheric lead and bromine in Germany. Post-abatement levels, variabilities and trends. Environ. Sci. Pollut., 9, 397-404.

26. Laugh, G. C., Schauer, J. J., Park, J. S., Shafer, M. M., Deminter, J. T., \& Weinstein, J. P. (2005). Emissions of metals associated with motor vehicle roadways. Environ. Sci. Technol., 39, 826-836. DOI: 10.1021/ es048715f. 